\title{
Study and Practice on the Optimization of Physical Teaching Theory Course Based on the New Curriculum Ideas
}

\author{
Ling Gan \\ Nanchangcityhealthschool 330006 Lingan56@sina.com
}

Key words: New curriculum ideas;Physical teaching theory course;Optimization

\begin{abstract}
The Physical Teaching Theory Course education, the contents of practice that moves with times, the educational reform of which based on the new curriculum ideas counts a lot to the whole physical education. Based on the analyses to the current situation of the education of Physical Teaching Theory Course under today's new curriculum ideas, this essay points out the necessity of reform and discusses the strategies. There are three of them: innovating educational ideas with times, a multi-pronged reform to teaching model, enriching qualified teaching contents.
\end{abstract}

\section{The current situation of the education of Physical Teaching Theory Course based on the new curriculum ideas}

\section{Problems exited in the system of the education of Physical Teaching Theory Course}

All the time, China's educative reform had been carried out at the premise of following the rules of education development. A scientific educational theory is crucial to the promotion of the reform and innovation of education, cultivating students' ideology as well as their innovation and practice ability. Physical Teaching Theory Course, as an important component of China's basic education curriculum, is of crucial significance to the furtherance of education reform. However, according to the current situation, there have been deficiencies in the education ideas of Physical Teaching Theory Course ${ }^{[1]}$.

For one thing, the Physical Teaching Theory Course is supposed to have its own distinctive function in developing students' literacy, but in the practical aspect, attention was paid only to the cultivating of knowledge and ability rather than ideology. There is little concern paid to the non-intellectual factors in nowadays reform, which to some extent affect the building of the Physical Teaching Theory Course education system.

On the other hand, some schools fail to value the building of the ideology system, and even fail to have a correct and comprehensive idea of the reform, losing its real intention.

\section{An incomprehensive study to the evaluation system of the Physical Teaching Theory Course education}

Constructing a scientific evaluation system of curriculum is essential in the study and practice of the reform of education of Physical Teaching Theory Course. From the current developing space of the reform, the building of a curriculum evaluation system also meets the requirements of the time of the new curriculum ideas. As a significant part of new curriculum ideas, the reform pushes the creative development of Physical Teaching Theory Course education.

In the curriculum evaluation system, two aspects, teachers' teaching evaluation and students' performance evaluation are often combined. In today's evaluation system, however, counting more on the evaluation of teachers in class, the excessively biased system emphasizes the excessive assessment on teachers and neglects the construction for a better students accorded evaluation system $^{[2]}$. Further more, some of the systems lack creativity--lagged ideology, with no innovation in the evaluation standards, not to mention the lacked comprehensive study to assessments of the teachers' teaching and the absence of students' evaluation system.

A comprehensive education evaluation system is crucial in the process of studying the innovative aspect of Physical Teaching Theory Course, without which a negative impact is doomed and in the 
long run would inevitably hinder the reform.

\section{The imperfection in the construction of Physical Teaching Theory Course education}

As a fundamental course of application type, the abundance of teaching resources is significant to the Physical Teaching Theory Course as a material insurance to the study of it. Thus, the construction of teaching resources should never be neglected ${ }^{[3]}$.

At present, the teaching resources of Physical Teaching Theory Course consist of the hardware and the software. The hardware teaching resources are the construction of school facilities, mainly reflected in the use of the resources. The software resources, including the construction of faculty resources, the optimization of education ideas and innovation of education model, are of greater importance to the hard ones, as they directly impact the teaching resources construction.

Nevertheless, there are problems. The principal one lies in the building of the faculty resources. Teachers, as the subject of education, should be active curriculum developers rather than conventional passive acceptors. But due to some objective factors, the teachers' role fail to transform properly, causing the delay of resources updating. It could be argued that the teachers' position is vital. The lack of thoroughness in developing the teaching resources will surely impact the reforming process, exerting passive effect to both the resource optimization and the course's innovation study.

\section{The necessity of the educational reform of Physical Teaching Theory Course based on the new curriculum ideas}

\section{Better for enriching learning experience}

The concept of the new curriculum is a kind of reforming ideas with creativity, focusing more on the innovation of teaching method at the premise of respecting students' development. This concept helped the education reform of Physical Teaching Theory Course with skill and ease, which had its best advantage in enriching students' learning experience by combining thinking and practicing together to guide students to be the subject and have first-hand experience of the learning delight ${ }^{[4]}$. As experiments are indispensable, students can do their best initiative in the process of learning.

Besides, the newly coming media instruction somehow added the experience. What's more, a far-reaching teaching plan can also improve the odds of practice and then their ability. In a word, the education reform of Physical Teaching Theory Course is a well done learning experience in cultivating cooperation working and words expressing.

\section{Better for definitions of learning goals}

In the process of the education reform of Physical Teaching Theory Course, the ultimate aim is to develop students' all-round quality and to maximize their abilities. The reform has made it came true. When setting the curriculum, teachers, as the subject of learning, should first let students know the contents of the course, then make them realize the importance of the Course with speculative knowledge, this macro cognition is crucial to students.

Meanwhile, students can clear and definite their own learning goals when receiving knowledge. Moreover, learning goals are also achieved by role shifting in this educative reform, in which students act as teachers in class ${ }^{[5]}$. Thus, accurately holding students' learning goals is one of the strengths in this educative reform based on the new curriculum ideas.

\section{Better for the case teaching of optimal curriculum}

Due to the concentration Physical Teaching Theory Course paid to the conjunction of practice and theory, applying multimedia technology and case teaching has become very popular. Since the application added more resources to the course itself as well as its contents. During the teaching process, relying on the multimedia technology, theoretical premise in essence with specific case 
teaching would let the students interact and communicate on the bases of learning excellent teaching skills and then enriching the substance of case teaching ${ }^{[6]}$.

In the age of new media, the informatization of teaching is the requirement of the new times and the pattern of educative reform, maximizing its function and mixing it subtlety with the Course would be one of the most significant expressions of the education reform on the base of new curriculum ideas.

\section{Strategies to the education reform of Physical Teaching Theory Course on the base of new curriculum ideas}

\section{To innovate education ideas with times}

Education concept has a great influence to the development of education reform, and having one that keeping abreast of the times is the needs and goals of the education development. It is vital for the education reform of the Physical Teaching Theory Course based on the new curriculum ,and work out its own concept with times.

To innovate education concept, schools should ideologically attach importance. The traditional closed teaching should transform into open teaching, giving more development space to education, and maximizing the schools' initiative. The pursuit to merely theory teaching should turned to the study of applying theory to practice, transferring the students' theory to the level of practice to strength their manipulative ability. Teaching should also transform from quantity to quality, stressing the cultivation of all-round ability. Therefore, on the way to the education reform of the Course, attention is supposed to be paid to the education reform, creating an education concept keeping up with times according to the requirement of the day.

\section{A multi-pronged reform to teaching model}

Reform of teaching model is multi-level, multi-angle and multi-faced in the background of educative reform of Physical Teaching Theory Course, it is necessary to give full play to the initiative, to have a multi-pronged transform to adapt to the process.

As for the schools, proactivity and bold innovation consciousness are needed to break the traditional single teaching mode, sublimating the process of teaching to the production and procession of knowledge, changing the traditional inputs and outputs developing mode, focusing more on the students and teachers. Schools should also actively publicize the merits of the teaching mode to the students, fully mobilizing their enthusiasm in the development. Teachers are supposed to reform and optimize the Course working in with the teaching, creating a teaching pattern keeping abreast of times. Thus, in innovating the teaching model, only on the basis of multi-force the educative reform is possible.

\section{To enrich qualified teaching contents.}

During the process of education reform of Physical Teaching Theory Course, a guarantee of internal quality is the priority among priorities, as a reform without any substantive changes makes no sense. So, having advance in internal teaching is essential.

To ensure the quality of teaching, objective analyses to the characteristics of the Course is needed on one hand, which demands the joint efforts of teachers and schools to make use of its advantages. Concentrating on the study of Physical Teaching Theory Course, schools are required to grasp the points of it accurately and have macro guidance and supervision. As for the teachers, they are supposed to have microscopic studies and discussions to the teaching to work out scientific teaching model, grasping the essence of qualified teaching.

On the other hand, only when fully realizing the function of qualified teaching in the Physical Theory Teaching Course that its practice significance can be fully and actively played. 


\section{References}

[1] David Lloyd, Bill Boyd, Kristin Den Exter. Mind mapping as an interactive tool for engaging complex geographical issues [J]. New Zealand Geographer .2010 (3).

[2] Ertu Evrekli, Didem nel, Ali Günay Bal?m. Development of a scoring system to assess mind maps [J]. Procedia - Social and Behavioral Sciences. 2010 (2).

[3] William Wraga, Peter Hlebowitsh. Toward a renaissance in curriculum theory and development in the USA [J]. Journal of Curriculum Studies .2003 (4).

[4] Brian Hudson. Holding complexity and searching for meaning: teaching as reflective practice [J]. Journal of Curriculum Studies .2002 (1).

[5] K. Gravemeijer, J. Terwel. Hans Freudenthal: a mathematician on didactics and curriculum theory [J]. Journal of Curriculum Studies .2000 (6) .

[6] Onno de Jong. The Teacher Trainer as Researcher: exploring the initial pedagogical content concerns of prospective science teachers [J]. European Journal of Teacher Education .2000 (2). 